\title{
Cambridge
}

\section{Opera in Portugal in the Eighteenth Century}

\section{MANUEL CARLOS DE BRITO}

This is the first detailed documentary history of opera in Portugal from the beginning of the eighteenth century to the inauguration of the still-existing Teatro de S. Carlos in 1793. The study examines the close links between Italian and Portuguese Opera, and shows how important the patronage of King José 1 was for the development of court opera and the fostering of work by a number of excellent native Portuguese composers $£ 30.00$ net $H B \quad 0521353122 \quad 275 \mathrm{pp}$.

\section{Cantonese Opera}

Performance as Creative Process

\section{BELL YUNG}

This book considers the creative process involved in the performance of Cantonese opera, in which as many as 60 singers/actors/dancers and a dozen or more instrumentalists take part in a performance staged usually without rehearsal or reference to musical notation. A cassette illustrating the music discussed is also available.

£35.00 net HB $0521305063275 \mathrm{pp}$

f13.95 net + VAT in UK Cassette 0521356326

\section{Alan Berg: Wozzeck}

\section{DOUGLAS JARMAN}

Alan Berg's Wozzeck is one of the most significant operas of the twentieth century. Douglas Jarman's study provides a clear and accessible introduction to this work, placing it in the context of the radical developments of the musical language in the early decades of the century and of the development of Berg's own musical style.

f27.50 net HB $0521241510 \quad 192 \mathrm{pP}$

f9.95 net $P B \quad 0521284813$

Cambridge Opera Handbooks

\section{Kurt Weill: The Threepenny Opera}

Edited by STEPHEN HINTON

The enduringly popular Threepenny Opera has given rise not only to interpretations as numerous as they are diverse, but also to new adaptations. This is the first book on the best-known of the Weill-Brecht collaborations to explore the extent and significance of the composer's contribution. Stephen Hinton provides a detailed reconstruction of the work's genesis and continued revision over three decades.

£30.00 net $\mathrm{HB} \quad 0521330262 \quad 256 \mathrm{pp}$. $£ 10.95$ net PB 0521338883

Cambridge Opera Handbooks

\section{Richard Strauss: Salome}

\begin{abstract}
Edited by DERRICK PUFFETT
This handbook is the first full-length study of Salome in English since Lawrence Gilman's introductory guide in 1907. It presents an informative collection of historical, critical and operas. There is a synopsis, bibliography and discography.

f30.00 net HB $0521351723 \quad 196 \mathrm{pp}$. f10.95 net PB 0521359708

Cambridge Opera Handbooks
\end{abstract} analytical studies of one of Strauss's most familiar

\section{Richard Strauss: Elektra}

\section{Edited by DERRICK PUFFETT}

The contributors to this handbook assemble the first full-length study of Elektra in English and they examine many facets of one of Strauss's most complex operas. The topics covered include the mythological background and Hoffmannsthal's adaptation of his sources, musical language, and a special study of the Klytamnestra scene. There is a synopsis, bibliography and discography.

£30.00 net $\mathrm{HB} \quad 0521351731 \quad 192 \mathrm{pp}$.

f10.95 net PB 0521359716

Cambridge Opera Handbooks

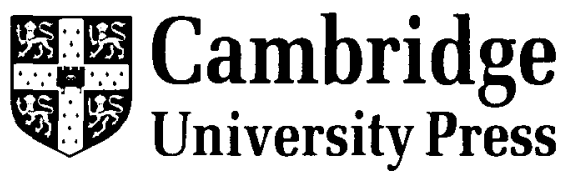

The Edinburgh Building, Cambridge CB2 2RU, UK 


\section{Early Music History}

Editor: lain Fenlon, King's College, Cambridge

\section{"Highly recommended for large collections, and for all academic libraries." Magazines for Libraries}

Early Music History is devoted to the study of music from the early Middle Ages to the seventeenth century. It demands the highest standards of scholarship from its contributors, all of whom are leading academics in their fields. The journal promotes interdisciplinary work and new methodologies as well as traditional approaches.

\section{Contents of Volume 9, 1990}

- Charles M. Atkinson Franco Cologne on the rhythm of organum purum

- Tim Carter Music-printing in late sixteenth- and early seventeenth-century Florence: Giorgio Marescotti, Cristofano Marescotti and Zanobi Pignoni

- Craig Monson Elena Malvezzi's keyboard manuscript : a new sixteenth century source

- Andrew Wathey The Peace of 1360-1369 and Anglo-French musical relations

- Rob C. Wegman Music and musicians at the Guild of our Lady in Bergen-opZoom, c. 1470-1510

Subscriptions 1990, Volume 9: $£ 22$ for individuals; $£ 35$ for UK institutions; $£ 38$ for institutions elsewhere; airmail $£ 8$ per year extra ISSN 0261-1279

To subscribe, or for further information, please contact:

Journals Publicity Department,

Cambridge University Press,

*FREEPOST, The Edinburgh Building,

Shaftesbury Road, Cambridge CB2 1BR,

England

( ${ }^{\star}$ No postage required if posted in the UK)

In US \& Canada contact: Cambridge University Press, 40 West 20th St, New York, NY 10011, USA

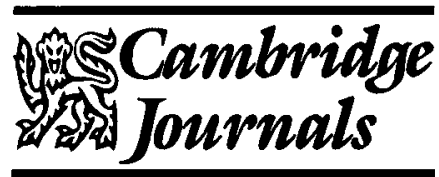




\section{British Journal of Music Education}

Editors: John Paynter, University of York;

Keith Swanwick, University of London Institute of Education

The principal concern of the journal is to develop debate about issues in music education and to do so without restriction of style, method, or specialism. A large proportion of contributors are practising teachers. An important part of the journal's production is the annual cassette tape with music examples related to articles published during the year.

\section{The range of subjects covered is wide:}

- classroom music teaching $\bullet$ individual instrumental teaching and group teaching $\bullet$ music in higher education $\bullet$ international comparative music education and the development of literature in this field.

Subscriptions 1990, Volume 7, March, July and November: $£ 19.00$ for individuals; $£ 29.00$ for UK institutions; $£ 33.00$ for institutions elsewhere; $£ 12.00$ for single parts; airmail $£ 9.50$ per year extra

ISSN 0265-0517

\section{Popular Music}

\section{Also from Cambridge}

Popular Music is a multi-disciplinary journal which covers all aspects of popular music broadly defined - from Abba to zydeco, from broadside ballads to hip-hop. It presents the results of scholarly work in an accessible form, while at the same time responding to current events. Each issue contains substantial articles, shorter topical pieces, news, correspondence and reviews.

Subscriptions 1990, Volume 9: January, May and October: $£ 22.00$ for individuals; $£ 40.00$ for institutions; $£ 15.00$ for single parts; airmail $€ 9.50$ per year extra ISSN 0261-1430

To subscribe, or for further information, please contact: Journals Publicity Department,

Cambridge University Press, "FREEPOST,

The Edinburgh Building, Shaftesbury Road,

Cambridge CB2 1BR, England

(*No postage required if posted in the UK)

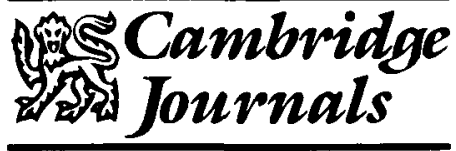




\section{British Journal of Music Education}

Editors: John Paynter, University of York;

Keith Swanwick, University of London Institute of Education

The principal concern of the journal is to develop debate about issues in music education and to do so without restriction of style, method, or specialism. A large proportion of contributors are practising teachers. An important part of the journal's production is the annual cassette tape with music examples related to articles published during the year.

\section{The range of subjects covered is wide:}

- classroom music teaching $\bullet$ individual instrumental teaching and group teaching $\bullet$ music in higher education $\bullet$ international comparative music education and the development of literature in this field.

Subscriptions 1990, Volume 7, March, July and November: $£ 19.00$ for individuals; $£ 29.00$ for UK institutions; $£ 33.00$ for institutions elsewhere; $£ 12.00$ for single parts; airmail $£ 9.50$ per year extra

ISSN 0265-0517

\section{Popular Music}

Popular Music is a multi-disciplinary journal which covers all aspects of popular music broadly defined - from Abba to zydeco, from broadside ballads to hip-hop. It presents the results of scholarly work in an accessible form, while at the same time responding to current events. Each issue contains substantial articles, shorter topical pieces, news, correspondence and reviews.

Subscriptions 1990, Volume 9: January, May and October: $£ 22.00$ for individuals; $£ 40.00$ for institutions; $£ 15.00$ for single parts; airmail $£ 9.50$ per year extra ISSN $0261-1430$

To subscribe, or for further information, please contact: Journals Publicity Department,

Cambridge University Press, "FREEPOST,

The Edinburgh Building, Shaftesbury Road,

Cambridge CB2 1BR, England

(*No postage required if posted in the UK)

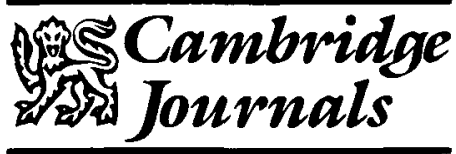




\section{GUIDELINES FOR CONTRIBUTORS}

Contributions may be sent to either editor:

Professor Roger Parker
Music Department
Lincoln Hall
Cornell University
Ithaca
NY 14853
USA

\author{
Professor Arthur Groos \\ Department of German Studies \\ Goldwin Smith Hall \\ Cornell University \\ Ithaca \\ NY 14853 \\ USA
}

The return of contributions cannot be guaranteed unless return postage is provided.

Manuscripts should be double spaced throughout (including footnotes, etc.) and should be typed on one side of the paper with ample margins. Contributors with word processors are requested to underline rather than use an italic font, and to avoid justification of right margins, automatic hyphenation and bold face type.

Footnotes should be numbered consecutively and be typed, double spaced, on separate pages at the end. Musical examples, figures, tables, etc. should also be supplied on separate sheets.

Contributors who wish to reproduce photographs should provide good black and white prints, full details of the source and the full address of the copyright holder if this differs. Photographs will not normally be considered unless they are an intrinsic part of the contribution, and their inclusion will always be at the discretion of the editors. The full address of the copyright holder should also be provided for any other material used in which the contributor does not hold copyright.

Punctuation should follow standard British practice. Single quotation marks should be used with double reserved for quotations within quotations. Punctuation that is not part of the quoted material should be outside closing quotation marks, as should footnote indicators. Longer quotations should be indented left without quotation marks and double spaced. Prose citations should be in English unless the original is of particular importance, unpublished or inaccessible, in which case the original should be followed by a translation in square brackets. Verse citations should be in the original language followed by a prose translation in square brackets.

Editorially added ellipses should be placed within square brackets [...] to distinguish them from any ellipses in quoted text and from the Italian punctuation ... . Dates should be on the following model: c. 1740, 1840s, 5 February 1943. References should be to: Act I scene 2, op. 1 no. 2 in E major, Ex. 12 and Exx. 12-14, Fig. 3 and Figs. 6-9, motif(s) and leitmotif(s). For precise identification of pitch, use this system:

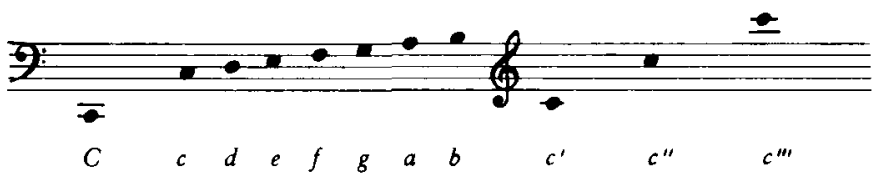

Sample footnotes (do not abbreviate journal titles):

1 John Whenham, Claudio Monteverdi: 'Orfeo', Cambridge Opera Handbooks, 3rd edn (Cambridge, 1996), 44-6.

2 Gerald Abraham, ed., The Age of Beethoven, 1790-1830, New Oxford History of Music, 8 (Oxford, 1982), 100-6.

${ }^{3}$ Curt von Westernhagen, Wagner: A Biography, trans. Mary Whittall, 2 vols. (Cambridge, 1978), II, 77f.

4 Winton Dean, 'French Opera', in Abraham, Beethoven, 137-46.

${ }^{5}$ Ernest Newman, The Life of Richard Wagner, IV (1947; rpt. New York, 1981), 212-15.

${ }^{6}$ Edgar Istel, 'Beethoven's Leonora and Fidelio', Musical Quarterly, 7 (1921), 228-31.

7 K. T. Rohrer, "'The Energy of English Words": A Linguistic Approach to Henry Purcell's Method of Setting Texts', Ph.D. diss. (Princeton University, 1980), 33.

${ }^{8}$ Rohrer, 249n3.

9 Whenham (see n. 1), 57.

First proofs may be read and corrected by contributors provided that they can give the editors an address through which they can be reached without delay and are able to return the corrected proofs, by airmail where necessary, within three days of receipt. 


\section{Now in paperback \\ The Cambridge Music Guide}

\section{Edited by STANLEY SADIE and ALISON LATHAM}

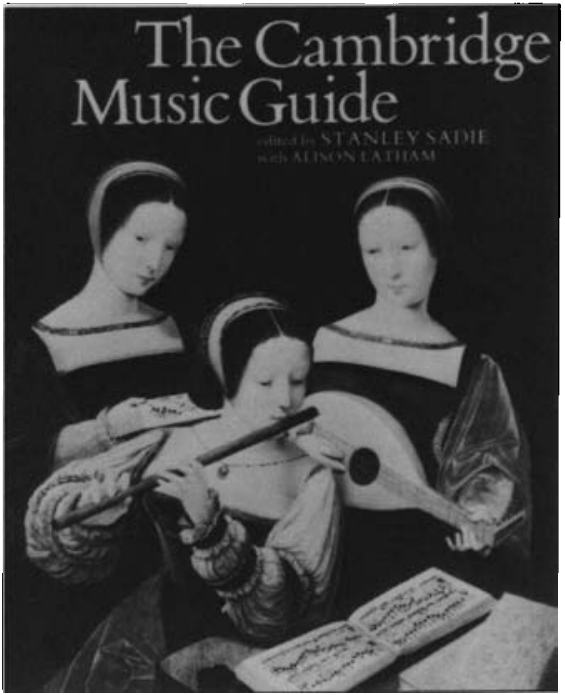

This comprehensive and beautifully illustrated guide to Western music is now available in paperback. Its expert contributors, under the editorship of Stanley Sadie, cover all aspects of music including notation, pitch and harmony, form and genre. The development of musical instruments is charted through the ages and the history of music itself is traced - from medieval plainchant right through to the popular music of today. This outstanding reference book should be on the shelves of everyone who is interested in, and enjoys, music.

Specialist contributions are made by Judith Nagley, Paul Griffiths and Wilfrid Mellers.

'Reautifully produced . . . copiously illustrated, would enrich any music-lover's library'

'Sumptuously produced ... the project has been carried out with enormous devotion and thoroughness.'

Music Teacher

'A sumptuous one-volume history of music . . .careful and well-organised.'

Times Literary Supplement

$£$ £4.95 Paperback ISBN 0521399424

For further information please contact Sarah Nichols

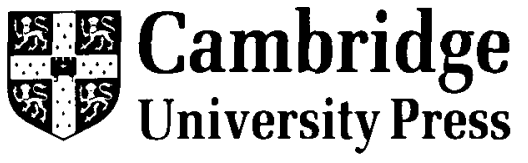

The Edinburgh Building, Cambridge CB2 2RU 